
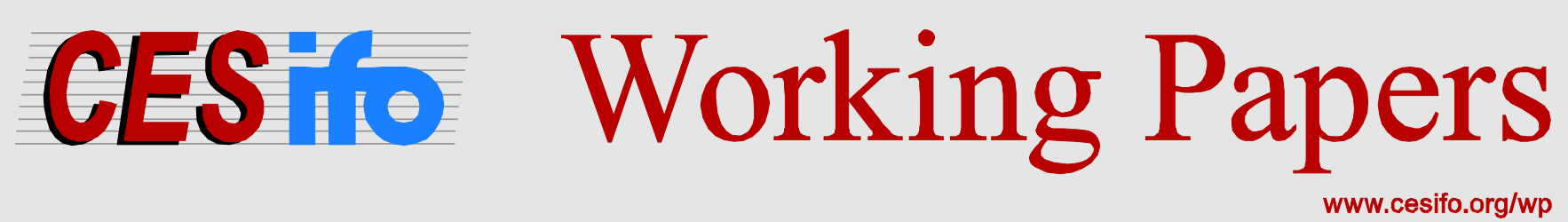

\title{
Wage Indexation and the Monetary Policy Regime
}

\author{
Selien De Schryder \\ Gert Peersman \\ Joris Wauters
}

\begin{abstract}
CESIFO WORKING PAPER NO. 5107
CATEGORY 7: MONETARY POLICY AND INTERNATIONAL FINANCE

DECEMBER 2014
\end{abstract}

An electronic version of the paper may be downloaded

- from the SSRN website: www.SSRN.com

- from the RePEc website:

- from the CESifo website:

www.RePEc.org

www.CESifo-group.org/wp 


\title{
Wage Indexation and the Monetary Policy Regime
}

\begin{abstract}
We estimate a New Keynesian wage Phillips curve for a panel of 24 OECD countries, and allow the degree of wage indexation to past inflation to vary according to the monetary policy regime. We find that the extent of wage indexation is significantly lower in an inflation targeting regime, in contrast to monetary targeting, exchange rate targeting and policy regimes without an explicit quantitative anchor. The results put into question whether embedding a constant degree of wage indexation in standard DSGE models is truly structural.
\end{abstract}

JEL-Code: C230, E420, J300.

Keywords: wage indexation, monetary policy regimes, cross-country panel, Phillips curve.

\author{
Selien De Schryder \\ Ghent University \\ Department of Financial Economics \\ Sint Pietersplein 5 \\ Belgium - 9000 Gent \\ selien.deschryder@ugent.be
}

\author{
Gert Peersman \\ Ghent University \\ Department of Financial Economics \\ Sint Pietersplein 5 \\ Belgium - 9000 Gent \\ gert.peersman@ugent.be
}

\author{
Joris Wauters \\ Ghent University \\ Department of Financial Economics \\ Sint Pietersplein 5 \\ Belgium - 9000 Gent \\ jorisL.wauters@ugent.be
}

November 2014

We thank Markus Eberhardt, Gerdie Everaert and Simon Price for constructive comments. We are grateful to Joshua Chan for sharing his replication files. We acknowledge financial support from the Research Foundation Flanders (FWO) and the Special Research Fund (BOF) of Ghent University. All remaining errors are ours. 


\section{Introduction}

New Keynesian dynamic stochastic general equilibrium (DSGE) models typically assume sticky wages and partial wage indexation to past inflation. Notably, the degree to which wages are indexed to past inflation is hard-wired as a fixed and policy invariant parameter (e.g. Christiano, Eichenbaum and Evans 2005, Smets and Wouters 2007). The assumption of a constant degree of wage indexation, however, has been rejected by institutional and empirical evidence for the United States (US). In particular, Holland (1986) documents a substantial rise in the proportion of wage contracts with indexation clauses to price level changes in the US between the late 1960s and mid 1980s, after which there was again a decline. Hofmann, Peersman and Straub (2012) estimate the extent of wage indexation in the US over time, and find a considerably higher degree of indexation during the "Great Inflation" of the 1970s compared to the earlier and later periods. Holland (1986) attributes the rise of indexation practices in the 1970s to much higher inflation uncertainty, whereas Hofmann et al. (2012) explain the rise and fall of wage indexation by a weaker reaction of the Federal Reserve to inflation during the "Great Inflation" and more aggressive inflation stabilization before and after this period. Specifically, a weakly inflation stabilizing monetary policy regime is conducive to high and volatile inflation, which fosters the use of wage indexation clauses as protection against inflation uncertainty.

To the extent that inflation uncertainty is determined by the monetary policy regime, a possible link between the degree of wage indexation and monetary policy is supported by economic theory. Gray (1978), for example, shows in a neoclassical model with wage rigidities that the optimal proportion of wage contracts indexed to inflation increases with the variance of monetary disturbances. Ehrenberg, Danziger and San (1983) further show in an efficient contract model that the gain of indexation for risk averse workers, and hence the likelihood of indexation, rises when inflation uncertainty is higher. On the other hand, Carrillo, Peersman and Wauters (2014) demonstrate that utility maximizing workers only want to index wages to past inflation when permanent shocks to the inflation target (and technology) dominate output fluctuations, but not when temporal inflation target (and aggregate demand) shocks dominate.

In this paper, we formally examine whether wage indexation varies across monetary policy regimes. ${ }^{1}$ More precisely, we estimate the reduced-form empirical New Keynesian wage Phillips curve of Galí (2011) on a panel dataset covering 24 OECD countries between 1960Q1 and 2011Q4, and allow the degree of wage indexation to vary according to the monetary policy regime. Since the monetary policy regime of an individual country is in general quite stable over time, a panel dataset approach increases the number of observations significantly, which allows us to formally estimate the role of the policy regime. To control for the effect of labour market institutions, we include the degree of labour market coordination and union density as additional possible explanatory variables.

\footnotetext{
${ }^{1}$ Although empirical work has found that higher inflation uncertainty raises the prevalence of costof-living adjustment clauses in collective wage bargaining agreements in the US (Holland 1986, Ragan and Bratsberg 2000), there is, to the best of our knowledge, no study showing that macroeconomic wage indexation varies systematically with monetary policy regimes.
} 
We identify the monetary policy regime of a country in a specific period based on the presence of an explicit quantitative monetary target, which takes three forms: inflation, money growth and exchange rates targets. Quantitative targets are transparent policy indicators and can easily be measured. ${ }^{2}$ A formal commitment to a quantitative target is expected to influence (improve) the formation of inflation expectations and (reduce) inflation uncertainty of workers (Mishkin 2007). We distinguish between the presence of an inflation, money growth and exchange rate target, because the underlying dynamics of these strategies and formation of inflation expectations are inherently different. For example, inflation targeting central banks typically try to stabilize inflation in the short to medium term, whereas money growth targeting is more a commitment to low inflation in the long run. ${ }^{3}$

The estimation results provide a number of important considerations for macroeconomic analysis and policymakers. First, we find that wage indexation is significant and economically relevant for the sample under analysis. Second, the results confirm that wage indexation varies across monetary policy regimes. The degree of wage indexation to past inflation turns out to be significantly lower in a regime which has a quantitative inflation target but this condition does not hold for money growth or exchange rate targets. Since the extent of wage indexation is different across monetary policy regimes, the constant indexation assumption embedded in standard DSGE models is susceptible to the Lucas (1976) critique, i.e. it is not intrinsic to the deep structure of the economy and not a policy invariant parameter. The analysis of alterations to the policy regime and counterfactual policy simulations in these models are thus potentially misleading. Similarly, the computation of optimal monetary policies that are conditional on the estimated parameters of these models may produce unreliable results if the optimal policy strategy implies changes to the degree of wage indexation and thus the structure of the economy.

Third, to the extent that having a quantitative inflation target itself is the key mechanism that lowers wage indexation to past inflation, the results suggest that the adoption of an explicit inflation target could reduce the inflationary consequences of shocks hitting the economy, the costs of disinflation, and the volatility of output and prices. ${ }^{4}$ Specifically, given that inflation is driven by real marginal costs, which are directly linked to wages, a significant reduction in the degree of wage indexation implies less amplification of the inflationary consequences of shocks hitting the economy due to mutually reinforc-

\footnotetext{
${ }^{2}$ There is a large literature that has focused on domestic institutions to represent the monetary policy regime, such as the degree of central bank independence and indicators of transparency (e.g. Alesina and Summers 1993, Eijffinger and Geraats 2006, Dincer and Eichengreen 2014). The use of such indicators, however, would reduce our panel dataset considerably. Moreover, the construction of these indicators involves debatable personal judgment.

${ }^{3}$ The inflationary outcomes of the three different types of nominal anchors also turn out to be different (Fatás, Mihov and Rose 2007).

${ }^{4}$ Based on the estimations, we can only conclude that the degree of wage indexation is different across monetary policy regimes, and significantly lower in regimes that have a quantitative inflation target. Whether the inflation target itself is the mechanism that reduces indexation practices is a question out of the scope of this paper. Specifically, other features of a monetary policy regime that are typically associated with an explicit inflation target could reduce the degree of wage indexation, for instance enhanced transparency, more independent central banks or an inflation averse society.
} 
ing feedback effects between wages and prices, i.e. less so-called second-round effects of inflationary shocks. A reduction in the inflationary effects of shocks hitting the economy requires in turn less aggressive monetary policy responses to stabilize inflation, lowering also output volatility (Hofmann et al. 2012).

Our work is related to several strands in the literature. Messina and Sanz-de-Galdeano (2014) use micro level data to document how Brazil's and Uruguay's disinflation policies changed the nature of wage rigidities. Alogoskoufis and Smith (1991) study wage and price inflation series from 1892 to 1987 for the US and the UK; they report coinciding shifts in the wage Phillips curve and price inflation persistence, which they link to departures from international fixed exchange rate regimes. Benati (2008) questions whether the intrinsic inflation persistence found in post-WWII US data is truly structural. He estimates the price Phillips curve on historical data for a set of countries and finds the price indexation parameter to be very low or zero under stable monetary policy regimes with clearly defined nominal anchors. Levin, Natalucci and Piger (2004) find that inflation expectations appear to be more forward looking, and inflation less persistent, in inflation targeting countries. A related study is also Fatás et al. (2007), who find that having an explicit quantitative target for monetary policy, in particular an inflation target, is systematically related to a lower average level of inflation. Finally, our study is related to the literature that analyses the role of monetary policy institutions for inflation outcomes and economic growth, such as central bank independence (Alesina and Summers 1993) and transparency (Sterne, Stasavage and Chortareas 2002, Eijffinger and Geraats 2006, Dincer and Eichengreen 2014).

The remainder of the paper is organized as follows: In the next section, we present the estimation results for a benchmark wage Phillips curve model with a constant degree of wage indexation. In section 3 , we extend the benchmark model to analyse the influence of the monetary policy regime on the extent of backward-looking wage indexation, while controlling for a set of labour market characteristics. Finally, section 4 concludes.

\section{Wage Phillips curve with constant indexation}

We first derive a benchmark empirical New Keynesian wage Phillips curve in section 2.1. Section 2.2 presents the data and discusses some econometric issues, and the estimation results are shown in section 2.3 .

\subsection{Model specification}

Our theoretical framework is based on Galí (2011), who derives the empirical wage Phillips curve from a New Keynesian model that includes the unemployment rate. He derives both a theoretical foundation for the empirical relation and a structural interpretation of the reduced form coefficients. The model assumes staggered wage setting as in Erceg, Henderson and Levin (2000), which means that a worker's wage cannot be re-optimized in every period. When the wage cannot be reset, it is assumed to be indexed to a weighted 
average of past price inflation $\left(\pi_{t-1}^{p}\right)$, the central bank's inflation target $\left(\pi^{*}\right)$ and trend productivity growth $(g): \gamma \pi_{t-1}^{p}+(1-\gamma) \pi^{*}+g$, with parameter $\gamma \in(0,1)$ determining the weights.

We denote wage inflation by $\pi_{t}^{w}$ and the difference between unemployment and the natural rate by $\hat{u}_{t} \equiv u_{t}-u^{n}$. The model's solution is given by

$$
\pi_{t}^{w}=\alpha+\gamma \pi_{t-1}^{p}+\psi_{0} \hat{u}_{t}+\psi_{1} \hat{u}_{t-1}
$$

with $\alpha \equiv(1-\gamma) \pi^{*}+g$ (Galí 2011, eq. 19).

Bringing (1) to a panel data setting results in the econometric benchmark wage inflation model:

$$
\pi_{i, t}^{w}=\alpha_{i}+\gamma \pi_{i, t-1}^{p}+\psi_{0} u_{i, t}+\psi_{1} u_{i, t-1}+\eta_{i, t},
$$

where subscripts $i$ and $t$ indicate the country and time period, and $\alpha_{i}$ represents $(1-$ $\gamma) \pi_{i}^{*}+g_{i}-\left(\psi_{0}+\psi_{1}\right) u_{i}^{n}$ plus additional country specific and time-invariant effects. Our main interest is the degree of indexation to past price inflation $(\gamma)$, which is expected to lie between 0 and 1 .

\subsection{Panel dataset and econometric considerations}

Our sample consists of an unbalanced panel covering quarterly data between 1960Q1 and 2011Q4 for 24 OECD economies. ${ }^{5}$ We use the information from a group of countries to broaden the information set and to increase the power of the tests. We consider the average hourly earnings of employees in the manufacturing sector as our measure of wages, sourced from the OECD MEI database. The earnings data are comparable to wage rate series that proxy for the basic wages or cost-of-living allowances, but they provide a more complete measure of the overall wage income because they also include premium pay for overtime and bonuses. ${ }^{6}$ Our price measure is the quarterly all-items consumer price index. We construct quarter-on-quarter wage and price inflation series as 100 times the log differences of the wage and price indices. We follow Galí (2011) in taking the average of the 4-quarter lags of past inflation as a smoothed price indexation measure. ${ }^{7}$ The unemployment rate is expressed as a percentage of the total labour force. Appendix A provides further details on the coverage and data definitions.

There are two issues of panel estimation that we need to take into account. First, we have to verify the appropriateness of homogeneous regression parameters. When the regression does not contain lagged dependent variables, as in equation (2), and the estimators are strictly exogenous, both homogeneous and heterogeneous estimators deliver

\footnotetext{
${ }^{5}$ The 24 countries are: Australia, Austria, Belgium, Canada, Czech Republic, Denmark, Estonia, Finland, France, Germany, Hungary, Ireland, Italy, South Korea, Netherlands, New Zealand, Norway, Poland, Portugal, Slovak Republic, Spain, Sweden, United Kingdom and the United States.

${ }^{6}$ Compensation rates, which also include employer contributions to social security or social insurance schemes, are a widely used alternative measure. However, this series is not available for 10 of the 24 countries in our sample.

${ }^{7}$ The main findings of this paper are robust to using past inflation instead of the smoothed measure.
} 
consistent coefficient estimates (Pesaran and Smith 1995). We nevertheless check whether the assumption of homogeneous parameters affects our small sample coefficient estimates by comparing Fixed Effects (FE) and Mean Group (MG) estimation results with a Wald test.

Second, macro panel estimates can be affected by cross-sectional dependence in the errors. Such dependence generally indicates the influence of factors which are common across countries, but not explicitly modelled. To ensure consistent estimates, we apply the cross section dependence test (CD test) of Pesaran (2004) to the residuals of the equations (2) and (4). If the test indicates a significant correlation between the cross section errors, we apply Common Correlated Effects (CCE) estimators. ${ }^{8}$

\subsection{Results}

Table 1 depicts the estimation results for the benchmark wage inflation model (2) in columns 1 and 2. A test on the homogeneity assumption of the coefficients validates the use of pooled estimators. ${ }^{9}$

The FE estimation in column 1 indicates a substantial degree of wage indexation to past inflation. The point estimate of $\gamma$ is 0.81 , which is within the estimated range of 0.52 and 0.83 obtained by Galí (2011) for the US. The negative contemporaneous and positive lagged effect of unemployment is in line with theoretical expectations (Galí, 2011). On impact, a 1 percentage point decline in the unemployment rate leads to a $0.37 \%$ increase in nominal wages. Heteroskedasticity and autocorrelation robust standard errors are employed for consistent inference. All parameters are statistically significant at the $1 \%$ level. The presence of a significant cross-sectional correlation in the residuals according to the CD test (bottom of Table 1) results makes a case for CCE estimators. Adding the cross section averages (CSAs) as regressors decreases the average residual correlation, although it remains significant (column 2). All coefficients decline to around half their previous size, with the indexation coefficient now attaining 0.41 .

Cogley and Sbordone (2008) argue that the price indexation parameter in a standard DSGE model becomes zero once a time-varying trend inflation of the central bank is introduced. As a robustness check, we have therefore also extended the estimated benchmark wage inflation model (2) with an estimated time-varying trend inflation (see Appendix B). The results are, however, the same (also the ones reported in the next section).

\footnotetext{
${ }^{8}$ The CCE estimators conveniently abstract from the possible influence of common factors by augmenting the observed regressors with the cross section averages (CSAs) of all variables, leaving least squares estimation still adequate. This approach yields consistent and asymptotically normal parameter estimates in a cross-country panel with a fairly large number of countries (Pesaran 2006).

${ }^{9}$ We performed the empirical analysis in STATA 12 with the user-written xtcd and xtmg routines of Eberhardt (2012). A Wald test on the null of coefficient homogeneity of FE versus MG generates an insignificant chi-square test statistic of 3.88. The Wald test on the CCE pooled and MG estimates also cannot reject the null of homogeneity (the test statistic is 2.36 ).
} 
Table 1: Results benchmark model

\begin{tabular}{llc}
\hline \hline Regressand: & \multicolumn{2}{c}{ wage inflation $\left(\pi_{i, t}^{w}\right)$} \\
\hline & $(1)$ & $(2)$ \\
& $\mathrm{FE}$ & $\mathrm{CCEP}$ \\
\hline Unemployment rate $\left(u_{t}\right)$ & $-0.374^{* * *}$ & $-0.195^{*}$ \\
& $(0.089)$ & $(0.103)$ \\
Lagged unemployment $\left(u_{t-1}\right)$ & $0.269^{* * *}$ & 0.108 \\
& $(0.090)$ & $(0.119)$ \\
Lagged price inflation $\left(\pi_{i, t-1}^{p}\right)$ & $0.806^{* * *}$ & $0.408^{* * *}$ \\
& $(0.043)$ & $(0.091)$ \\
\hline CD test (average correlation) & 0.090 & -0.035 \\
CD test (statistic and p-value) & 15.95 & -5.73 \\
& 0.000 & 0.000 \\
\hline \hline Note: ${ }^{* * *},{ }^{* * *}$ denote significance at 10,5, and $1 \%$ levels respectively \\
Robust standard errors are in brackets & \\
Sample: $\bar{T}=141$, max $T=207$, min $T=47$ and $\mathrm{N}=24$ \\
\hline
\end{tabular}

\section{Wage Phillips curve with variable wage indexation}

\subsection{Linking wage indexation to monetary policy}

A number of theoretical studies conclude that the degree of wage indexation to past inflation may depend on inflation uncertainty and the conduct of monetary policy. Specifically, Gray (1978) presents a neoclassical model with short-term wage rigidities and uncertainty, and shows that the degree of wage indexation that minimizes the deviation of output from full-information output increases with the variability of monetary disturbances. Ehrenberg et al. (1983) demonstrate in an efficient contract model that a rise in inflation uncertainty may lead to greater use of wage indexation because wage indexation helps to insulate the worker's real wage from the effects of unanticipated inflation, whereas it reduces the impact of lower-than-anticipated inflation on the real cost of labour inputs for firms. Carrillo et al. (2014) show that utility maximizing wage setters raise the extent of wage indexation to past inflation when the variability of permanent shocks to the inflation target of the central bank increases, whereas the amount of indexation declines when there is a rise in the volatility of temporal inflation target shocks.

A possible link between wage indexation, inflation uncertainty and monetary policy is also supported by institutional and empirical evidence for the US. Holland (1986) demonstrates that the proportion of cost-of-living adjustment clauses in major collective bargaining agreements was much higher in the 1970s and first half of the 1980s than the preceding and subsequent periods. He finds that this pattern can be explained by a sizeable increase of inflation uncertainty in the 1970s, measured by the mean squared forecast error of inflation surveys. Hofmann et al. (2012) estimate the evolution of US wage dynamics over time, and find a degree of wage indexation to past inflation of 0.91 during the 
"Great Inflation" of the 1970 s, compared to 0.30 and 0.17 before and after this period. ${ }^{10}$ Hofmann et al. (2012) argue that this evolution can be explained by a shift in the monetary policy reaction function of the Federal Reserve. More specifically, a weakly inflation stabilizing conduct of monetary policy in the 1970s resulted in high and volatile inflation, which encouraged the use of indexation clauses in wage contracts as a protection against inflation uncertainty. Conversely, the credible establishment of price stability after the disinflation of the early 1980s reduced the need for protection against unforeseen inflation, thus mitigating wage indexation. ${ }^{11}$

Both theory and empirical evidence thus suggest that the assumption of a constant degree of wage indexation in a wage Phillips curve is questionable. However, although the degree of wage indexation in the US was definitely higher during the "Great Inflation" compared to earlier and later periods, it is not clear whether this was indeed the consequence of monetary policy. For example, the 1970s were also characterized by very volatile supply shocks, whilst changes in labour market institutions may also have played a role. It is also not clear whether a link between indexation and the conduct of monetary policy can be established in other countries. In the rest of this paper, we formally examine the influence of the monetary policy regime on wage indexation within our panel dataset of 24 OECD countries.

\subsection{Characteristics of Monetary policy regimes}

We identify the monetary policy regime by the presence of an explicit quantitative monetary target. It is commonly accepted that a policy regime that clearly commits to a nominal anchor can help promote price stability and stabilize inflation expectations (Mishkin 2007). A quantitative monetary target should help to lower inflation uncertainty. Accordingly, also the degree of wage indexation is expected to be lower in a monetary policy regime with an explicit nominal anchor. The advantage of defining a policy regime by the presence of a quantitative target is that it can easily be measured and verified in an objective and mechanistic way (Fatás et al. 2007).

There exist different types of nominal anchors, and in this work, we consider three different monetary target strategies: the inflation rate, the exchange rate and the money supply. These three frameworks have distinct characteristics. Under inflation targeting, policy decisions are based on conditional medium-run inflation forecasts. Its high degree of transparency and accountability further allows for close monitoring by the private sector

\footnotetext{
${ }^{10}$ Hofmann et al. (2012) first estimate a time-varying parameters Bayesian structural vector autoregressive (TVP-BVAR) model, and document considerable time variation in the impulse responses of wages and prices to aggregate supply and demand shocks. In a second step, the parameters of a standard DSGE model containing a wage Phillips curve are estimated for respectively 1960Q1, 1974Q1 and 2000Q1, by matching the impulse responses from the TVP-BVAR for these periods with the impulse responses of the DSGE model using a Bayesian impulse response matching procedure.

${ }^{11}$ Similar to Hofmann et al. (2012), Muto and Shintani (2014) perform an empirical evaluation of the New Keynesian Wage Phillips Curve for Japan and the US. They show with rolling window regressions that the importance of wage indexation has declined over time for both countries, which they explain via lower and more stable inflation.
} 
(Svensson 1999). A fixed exchange rate target is also easily communicated to the public, but monetary policy cannot react to domestic shocks independently from the anchor country. This restriction makes the fixed exchange rate vulnerable to speculative attacks, which increases inflation uncertainty. Money growth targeting also offers a transparent anchor to the public, but this strategy should be seen primarily as a way to communicate a commitment to low and stable inflation in the long run (Issing 1996). Targeting a money aggregate can lead to more inflation uncertainty in the short to medium term due to the unstable relationship between inflation and money aggregates and the presence of money demand shocks.

Figure 1: Monetary regimes

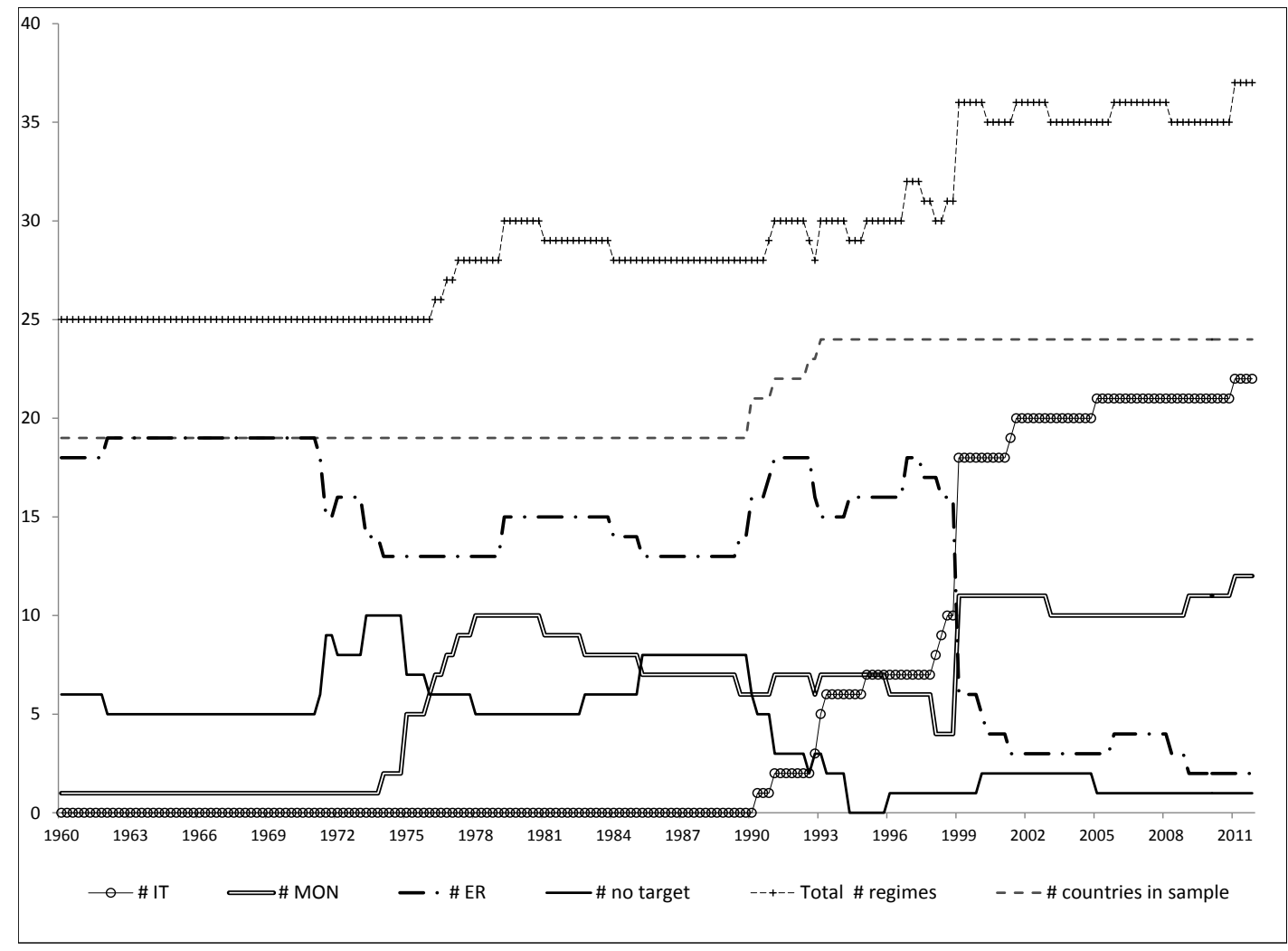

This distinction is also validated by the empirical literature analysing the macroeconomic outcomes of different monetary regimes. Fatás et al. (2007), for instance, find that an inflation targeting regime lowers inflation significantly more than an exchange rate or a monetary targeting regime. Furthermore, inflation targeting has anchored inflation expectations (Walsh 2009) and lowered inflation persistence (Mishkin and Schmidt-Hebbel 2007). ${ }^{12}$ Fixed exchange rate regimes have in some cases been linked to greater output volatility and lower and more stable inflation (Ghosh, Gulde, Ostry and Wolf 1997; Levy-

\footnotetext{
${ }^{12}$ For evidence that inflation targeting leads to better anchored inflation expectations, see e.g. Gürkaynak, Levin and Swanson (2010); Gürkaynak, Levin, Marder and Swanson (2007) and Levin et al. (2004).
} 
Yeyati and Sturzenegger 2001). Monetary target regimes have been found to keep inflation under control in the longer run by means of a flexible approach towards the target rule and an active and elaborate communication of the monetary policy strategy to the public (Mishkin 1999).

Figure 1 summarizes the evolution of the monetary regimes for the countries in our sample. The overall pattern is consistent with the shifts in policy regimes documented in the literature (Fatás et al. 2007). Exchange rate targeting was the dominant regime during the 1960s and early 1970s, while in the mid-1970s some countries shifted to monetary targeting. ${ }^{13}$ Since the early 1990s, a lot of countries switched to inflation targeting, which becomes the dominant policy framework at the end of the sample. We classify EMU members as having both an inflation and a monetary target since the emergence of the European Central Bank in 1999, which is why the series jump at this point. Notice that the total number of regimes increases over time and always exceeds the number of countries. This can be explained by a declining trend in the number of countries without a formal target and countries combining different targets. Table 2 shows that there are 55 of regime switches in total. ${ }^{14}$ We conclude that there is quite some variation in the data in terms of policy regime shifts.

Table 2: Summary statistics: Regime switches

\begin{tabular}{c|c|c|c|c}
\hline From To & ER & MON & IT & No target \\
\hline ER & - & 8 & 12 & 13 \\
\hline MON & 1 & - & 2 & 3 \\
\hline IT & 0 & 0 & - & 0 \\
\hline No Target & 5 & 6 & 5 & - \\
\hline
\end{tabular}

Note: ER, MON \& IT stand for resp. exchange rate targeting, monetary targeting and inflation targeting.

\subsection{Econometric model specification}

We explore whether the degree of wage indexation varies according to the monetary policy regime, by extending the benchmark wage Phillips curve of section 2 with interaction terms:

$$
\begin{gathered}
\pi_{i, t}^{w}=\alpha_{i}+\widetilde{\alpha}^{\prime} D_{i, t}+\gamma \pi_{i, t-1}^{p}+\widetilde{\gamma}^{\prime} D_{i, t} \pi_{i, t-1}^{p}+\psi_{0} u_{i, t}+\psi_{1} u_{i, t-1}+\eta_{i, t} \\
\text { where } \mathrm{D}_{i, t} \equiv\left(\operatorname{REGIME}_{i, t}, \mathrm{UD}_{i, t}, \operatorname{COORD}_{i, t}\right)^{\prime}
\end{gathered}
$$

\footnotetext{
${ }^{13}$ Exchange rate frameworks characterized as a managed or free float are not considered as an exchange rate targeting regime.

${ }^{14}$ Of the 55 cases, only 6 cases are "double counted" because a country with one target switched to a regime with 2 other targets, and vice versa. If we also include cases where there is a change in the policy regime without abandoning the regime already in place (including cases where, for instance, a monetary targeter adds an inflation target as second objective), we obtain a total of 70 regime changes.
} 
$D_{i, t}$ is a $k \times 1$ vector of variables that are interacted with past inflation and the constant $\alpha_{i}$, whereas $\widetilde{\alpha}$ and $\widetilde{\gamma}$ are $k \times 1$ vectors with the corresponding interaction coefficients. ${ }^{15}$ Following Fatás et al. (2007), we asses whether having a monetary target matters in the first place, and distinguish between the type of target in a second step. ${ }^{16}$ The policy regime interaction dummies (REGIME) therefore indicate the presence of an explicit quantitative monetary target (TARGET), or respectively an inflation target (IT), a money growth target (MON) or an exchange rate target (ER).

We control for possible effects of changes in the wage bargaining process on indexation by including the coordination level of wage bargaining (COORD) and the union density rate (UD) in the estimations. Cecchetti (1987), for instance, documents that policy interventions in the bargaining process in the US during the 1960s and early 1970s altered both the effective degree of indexation and the frequency of union wage changes. Recent empirical evidence of Gnocchi and Pappa (2013) shows that wage bargaining reforms that reduced the centralization of wage bargaining have led to changes in wage dynamics. Messina and Sanz-de-Galdeano (2014) relate the different evolution of wage indexation in Uruguay and Brazil to the dynamics in the centralization level of wage bargaining and changes in the union coverage. The authors find that a decline in union coverage and a more decentralized wage bargaining reduces wage indexation. Carrillo et al. (2014) further show that the economy's equilibrium degree of wage indexation can differ depending on whether the labour market coordination is centralized or decentralized.

We use the coordination level of wage bargaining to capture the degree to which major institutional players' decisions extend to lower-level institutions and the percentage of workers that are affiliated with a labour union to control for the power of labour unions in wage bargaining negotiations. The coordination variable ranges from 1 (decentralized) to 5 (highly centralized), while the union density rate is expressed as a percentage. Figure 2 shows the evolution over time in the coordination measure for the countries in our sample. The proxy varies strongly across countries and time, and there is also a difference in the extent of time variation across countries (compare, e.g., Norway to the US). The same message holds for the union density rate, depicted in figure 3, although most countries seem to experience a downward or stable trend over time.

\subsection{Results}

We now discuss the estimation results of the wage Phillips curve with interaction variables, for which we only report FE estimates. In contrast to the benchmark model, the CCEP estimator is not suitable for the interaction effects model. The reason for this limitation is explained in table 3, which gives an overview of the mean and median correlation

\footnotetext{
${ }^{15}$ Interacting with the intercept prevents the estimation of spurious interaction effects (Brambor, Clark and Golder 2006).

${ }^{16}$ Note however that the number of countries in our sample without a formal monetary target has become increasingly smaller over time and is especially limited since the 1990s (see figure 1). The size of this group of countries with no formal and explicit monetary target should therefore be taken into account when interpreting the results in the next section.
} 
Figure 2: Degree of wage bargaining coordination (index: 1-5)

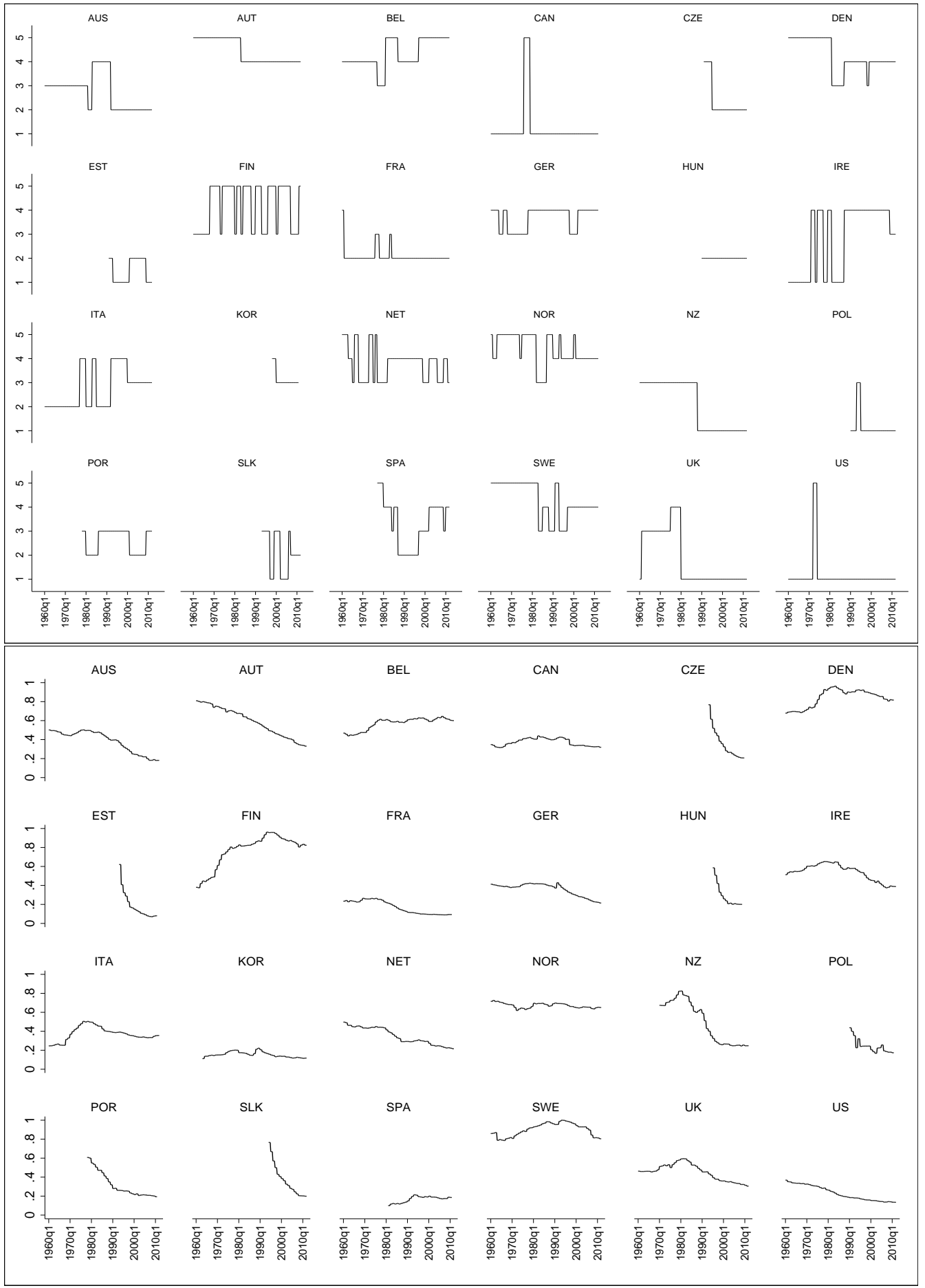

Figure 3: Union density rate 
of the country-specific regime and labour market indicators with their respective CSA for the entire group of countries. The correlations are quite high, up to $90 \%$ and more for the inflation target dummy, which indicates that changes in the interaction variables are synchronized in time across countries. This result makes controlling for their CSAs unattractive, as they will interfere with our goal of measuring the influence of the policy regime on $\gamma$. In addition, we found that including the CSAs of the other (non-interacted) variables does not lead to further important reductions in the extent of cross-sectional residual correlation. We have therefore decided not to apply the CCE estimators for the estimation of the interaction model.

Table 3: Cross-country correlations

\begin{tabular}{cccccc}
\hline \hline \multicolumn{5}{c}{ Correlation interaction variables with } & their CSA \\
\hline & IT & ER & MON & COORD & UD \\
mean & 0.88 & 0.40 & 0.78 & 0.29 & 0.61 \\
median & 0.92 & 0.51 & 0.81 & 0.32 & 0.78 \\
\hline
\end{tabular}

Table 4 reports the estimates of equation (3) with the monetary regime interaction variables. At the bottom of the table, we report the average degree of indexation in each regime. ${ }^{17}$ The first column indicates that monetary policy regimes with a quantitative monetary target, irrespective of the type of target, have a degree of wage indexation to past inflation which is on average not significantly lower than regimes without a quantitative target.

A closer look at the effect of an inflation, money growth or exchange rate target, provided in column 2, shows that the type of target matters. Specifically, the degree of wage indexation is on average 0.60 lower in policy regimes that have an explicit inflation target. With the labour market variables set to their sample means, wage indexation to past inflation is even statistically insignificant for countries with a quantitative inflation target. In contrast, a money growth or exchange rate target has no substantial effect on the degree of indexation. ${ }^{18}$ The estimated degree of wage indexation for both regimes is respectively 0.82 and 0.73 . Finally, the level of coordination and the union density rate exert no significant influence on $\gamma \cdot{ }^{19}$ In sum, only the presence of an explicit inflation target seems to reduce the extent of wage indexation in OECD countries.

\footnotetext{
${ }^{17}$ Total indexation equals $\partial \pi_{i, t}^{w} / \partial \pi_{i, t-1}^{p}=\gamma+\tilde{\gamma}^{\prime} D_{i, t}$. Standard errors are computed with the Delta method.

${ }^{18}$ The substantial reduction of indexation under inflation targeting is robust to using the first or fourth lag of the regime dummies. The effect is also robust to including a time-varying inflation target. These results are available from the authors on request.

${ }^{19}$ We also tested for a possible non-linear relationship of the extent of COORD and UD on wage indexation in the spirit of Calmfors and Driffill (1988), but the quadratic effects were found to be statistically insignificant.
} 
Table 4: Results interaction model

\begin{tabular}{|c|c|c|}
\hline \multicolumn{3}{|c|}{ Regressand: wage inflation $\left(\pi_{i, t}^{w}\right)$} \\
\hline & $(1)$ & $(2)$ \\
\hline Unemployment rate $\left(u_{i, t}\right)$ & $\begin{array}{l}-0.370^{* * *} \\
(0.089)\end{array}$ & $\begin{array}{l}-0.334^{* * *} \\
(0.092)\end{array}$ \\
\hline Lagged unemployment $\left(u_{i, t-1}\right)$ & $\begin{array}{l}0.247^{* * *} \\
(0.087)\end{array}$ & $\begin{array}{l}0.214^{* *} \\
(0.091)\end{array}$ \\
\hline Lagged price inflation $\left(\pi_{i, t-1}^{p}\right)$ & $\begin{array}{l}0.979^{* * *} \\
(0.138)\end{array}$ & $\begin{array}{l}0.961^{* * *} \\
(0.109)\end{array}$ \\
\hline \multicolumn{3}{|l|}{ Interactions: } \\
\hline COORD & $\begin{array}{l}0.015 \\
(0.027)\end{array}$ & $\begin{array}{l}0.010 \\
(0.021)\end{array}$ \\
\hline UD & $\begin{array}{c}-0.316 \\
(0.253)\end{array}$ & $\begin{array}{l}-0.350 \\
(0.230)\end{array}$ \\
\hline TARGET & $\begin{array}{c}-0.157 \\
(0.114)\end{array}$ & - \\
\hline IT & - & $\begin{array}{l}-0.598^{* *} \\
(0.224)\end{array}$ \\
\hline MON & - & $\begin{array}{r}-0.031 \\
(0.083)\end{array}$ \\
\hline ER & - & $\begin{array}{l}-0.126 \\
(0.096)\end{array}$ \\
\hline \multicolumn{3}{|c|}{ Total indexation effect [COORD \& uD at means] } \\
\hline Absence of quantitative TARGET & $0.897^{* * *}$ & $0.852^{* * *}$ \\
\hline Presence of quantitative TARGET & $0.740^{* * *}$ & - \\
\hline Inflation targeting regime (IT) & - & 0.254 \\
\hline Monetary targeting regime (MON) & - & $0.820^{* * *}$ \\
\hline Exchange rate targeting regime (ER) & - & $0.725^{* * *}$ \\
\hline CD test (average correlation) & 0.078 & 0.052 \\
\hline CD test (statistic and p-value) & $\begin{array}{l}13.14 \\
0.000\end{array}$ & $\begin{array}{l}9.38 \\
0.000\end{array}$ \\
\hline
\end{tabular}

Note: ${ }^{*}, * *{ }^{* * *}$ denote significance at 10,5 , and $1 \%$ levels, respectively.

Robust standard errors in brackets. Sample: $\mathrm{N}=24, \bar{T}=137, \min T=43, \max T=207$

$\pi_{i, t-1}^{p}$ coefficient shows level of backward-looking indexation when all interactions $D_{i, t}=0$. 


\section{Conclusions}

We have examined the standard assumption in New Keynesian DSGE models that wage indexation to past price inflation is invariant to policy regimes. In particular, we have estimated the reduced form empirical wage Phillips curve of Galí (2011) with a panel model for 24 advanced economies, and allowed the degree of backward-looking wage indexation to vary according to the monetary policy regime while controlling for the evolution of labour market institutions.

We find that wage indexation to past inflation varies across monetary policy regimes. Specifically, the degree of wage indexation in an inflation target regime is both statistically insignificant and significantly lower than indexation in a regime without a target. In contrast, regimes with money and exchange rate targets have statistically significant indexation levels, and these levels are not significantly different from a regime without any formal quantitative target. These differences could be due to varying strengths of the nominal anchor under the different frameworks, as inflation targeting has been found to establish better anchored inflation expectations (Mishkin and Schmidt-Hebbel 2007, Walsh 2009), which, in turn, could strengthen the nominal anchor.

Overall, our results question the structural nature of hard-wiring a fixed degree of wage indexation in standard DSGE models. Our work corroborates and extends the finding of Hofmann et al. (2012) of substantial time variation in the degree of wage indexation for the US. It further shows that the monetary policy dependence of price indexation found by Benati (2008) can be extended to wage indexation. From a policy standpoint, our findings suggest that counterfactual policy simulations and the analysis of optimal monetary policy based on modern macroeconomic models are potentially misleading.

Our work provides empirical support for research that aims to endogenise the extent of wage indexation in structural models. Some steps have already been taken by Wieland (2009) and Carrillo et al. (2014), but further research in this direction is warranted. 


\section{Appendix A: Data sources and construction of variables ${ }^{20}$}

Hourly earnings: average total earnings in manufacturing paid per employee per hour, index $2010=100$, seasonally adjusted [OECD, Main Economic Indicators database, quarterly frequency].

Note: The earnings series constitutes wage rates plus overtime payments, bonuses and gratuities regularly and irregularly paid, remuneration for time not worked, and payments in kind. Not included are employer contributions to social security or insurance schemes and unfunded employee social benefits paid by employers. Adding these components to the earnings series delivers compensation rates.

Unemployment rate: the unemployment rate is defined as the ratio of the number of unemployed workers to the working population [OECD, Main Economic Outlook No.93, quarterly frequency].

Note: The German series prior to 1992 were extended backwards based on the growth rates of unemployment rate as percentage of civilian labour force for West-Germany (source: Bundesbank, series BBK01.USCY01).

Prices: consumer price index, all items, index $2010=100$, seasonally adjusted by Census X12 [OECD, Main Economic Indicators database, quarterly frequency].

Monetary policy quantitative target dummies: 0-1 dummy variables, which indicate if a country has a formal inflation, exchange rate or monetary target in the respective time period. If an exchange rate regime is classified as having a managed or freely floating exchange rate, we consider it to have no formal target [quarterly frequency].

Our main sources for the classification of quantitative monetary targets are Fatás et al. (2007) and Houben (2000). An additional source for inflation targeting regimes is Rose (2007); for exchange rate and monetary targeting regimes, it is Borio and White (2003).

Note: Conflicting dates were examined and remaining gaps were filled based on central banks' websites, individual central bank reports and, where necessary, additional publications.

Coordination: indicator of degree of wage coordination ranging from 1 (fragmented wage bargaining, confined largely to individual firms or plants) to 5 (centralized bargaining by peak association(s), with or without government involvement) [ICTWSS database version 4.0 from Visser (2013) (Amsterdam Institute for Advanced Labour Studies), annual frequency, 1960-2011].

\footnotetext{
${ }^{20}$ We initially started from a data sample of 29 OECD countries over 1960Q1-2013Q2. Due to data availability of the labour market indicators, the sample was limited to 2011Q4 and 3 countries were dropped (Iceland, Israel and Mexico). We further eliminated Japan and Luxembourg from the sample as these countries are characterized by severe outliers concerning the coefficients on the unemployment rate variables.
} 
Trade union density: the trade union density rate is defined as the ratio of the number of wage and salary earners that are trade union members to the total number of wage and salary earners [OECD, Labour statistics, annual frequency, 1960-2011].

Trend inflation: for each country, we estimate trend inflation with the AR-Trendbound model of Chan et al. (2013) (see appendix B). The model delivers estimates of a central bank's time-varying inflation target, which is restricted to lie within bounds, based on diffuse uniform priors.

Table 5: Overview number of observations per country

\begin{tabular}{|c|c|c|c|c|c|c|c|}
\hline country & \multicolumn{2}{|c|}{ time span } & \# & country & \multicolumn{2}{|c|}{ time span } & \# \\
\hline Australia & 1984Q2 & 2011Q4 & 111 & Italy & 1960Q2 & 2011Q4 & 207 \\
\hline Austria & 1969Q2 & 2011Q4 & 171 & Korea, South & 1992Q2 & 2011Q4 & 79 \\
\hline Belgium & 1960Q2 & 2011Q4 & 207 & Netherlands & 1970Q2 & 2011Q4 & 167 \\
\hline Canada & 1960Q2 & 2011Q4 & 207 & New Zealand & 1989Q2 & 2011Q4 & 91 \\
\hline Czech Republic & 1993Q2 & 2011Q4 & 75 & Norway & 1960Q2 & 2011Q4 & 207 \\
\hline Denmark & 1971Q2 & 2011Q4 & 163 & Poland & 1995Q2 & 2011Q4 & 67 \\
\hline Estonia & 2000Q2 & 2011Q4 & 47 & Portugal & 2000Q2 & 2011Q4 & 47 \\
\hline Finland & 1960Q2 & 2011Q4 & 207 & Slovak Republic & 1993Q3 & 2011Q4 & 74 \\
\hline France & 1960Q2 & 2011Q4 & 207 & Spain & 1981Q2 & 2011Q4 & 123 \\
\hline Germany & 1962Q2 & 2011Q4 & 199 & Sweden & 1971Q2 & 2011Q4 & 163 \\
\hline Hungary & 1995Q2 & 2011Q4 & 67 & United Kingdom & 1963Q2 & 2011Q4 & 195 \\
\hline Ireland & 1990Q2 & 2011Q4 & 87 & United States & 1960Q2 & 2011Q4 & 207 \\
\hline
\end{tabular}




\section{Appendix B: Estimation results with time-varying trend in- flation}

As a robustness check we extend the benchmark wage inflation model (2) with a timevarying inflation target of the central bank $\left(\pi_{t}^{*}\right)$. This exercise is motivated by Cogley and Sbordone (2008), who find that extending a standard DSGE model with a time-varying trend inflation rate results in a low and insignificant degree of price indexation. ${ }^{21}$

Compared to the benchmark wage inflation model (2), trend inflation is no longer in the intercept, but becomes a right hand side variable instead. Accordingly, specification (2) is extended to a benchmark wage gap model form:

$$
\tilde{\pi}_{i, t}^{w}=\alpha_{i}+\gamma \tilde{\pi}_{i, t-1}^{p}+\psi_{0} u_{i, t}+\psi_{1} u_{i, t-1}+\eta_{i, t},
$$

where $\tilde{\pi}_{t}^{w} \equiv \pi_{t}^{w}-\pi_{t}^{*}$ and $\tilde{\pi}_{t-1}^{p} \equiv \pi_{t-1}^{p}-\pi_{t}^{*} \cdot{ }^{22}$

The AR-trend-bound model for trend inflation For each country in our sample, we estimate trend inflation using the model of Chan, Koop and Potter (2013). ${ }^{23}$ For details on the model, we refer the reader to their paper. We next discuss how our priors differ from theirs.

We set relatively diffuse uniform priors for the lower and upper bounds as $a \sim U(\underline{a}, \bar{a})$ and $b \sim U(\underline{b}, \bar{b})$ for each country (see table 6 ). Keep in mind that these bounds apply to quarter-on-quarter non-annualized growth rates of the consumer price index and that some countries experienced significantly high inflation rates. Relative to their setup, we make initial conditions more diffuse by setting $\omega_{\pi^{*}}^{2}=\omega_{h}^{2}=25$ and set $\pi_{0}^{*}$ equal to the mean of the first four observations of the inflation series. Furthermore, we only restrict the inflation gap to be stationary: $-1<\rho_{t}<1 \forall t$. Concerning the inverse gamma priors for the error variances, we follow Cogley and Sargent (2005) in placing the most weight on the sample information by using an IG prior with a single degree of freedom for all three variances: $\sigma_{\pi^{*}}^{2}, \sigma_{\rho}^{2}$ and $\sigma_{h}^{2} \sim I G\left(\frac{1}{2}, \frac{0.01^{2}}{2}\right)$.

\footnotetext{
${ }^{21}$ Cogley and Sbordone (2008) extend the Calvo pricing model in a standard DSGE model to incorporate drifts in trend inflation and derive a reduced form New Keynesian Phillips Curve (NKPC) with time-varying coefficients. This reduced form NKPC is estimated on US data by means of a Bayesian time-varying VAR. Under the assumption that non-optimized prices are fully indexed to a mixture of current trend inflation and one-period lagged inflation, the reduced form NKPC collapses to a more traditional NKPC based on the inflation gap with constant coefficients and without additional forward-looking terms. The latter specification is similar to our benchmark wage gap model.

${ }^{22}$ Equation (4) is obtained by assuming that the coefficients on past and trend inflation $\left(\gamma\right.$ and $\left.\gamma^{*}\right)$ in $\pi_{i, t}^{w}=\alpha_{i}+\gamma \pi_{i, t-1}^{p}+\gamma^{*} \pi_{i, t-1}^{*}+\psi_{0} u_{i, t}+\psi_{1} u_{i, t-1}+\eta_{i, t}$ sum to one. This hypothesis is not rejected by a Wald test (value $=1.04, \mathrm{~F}$-statistic $=0.26$, p-value $=0.61$ ). Note that we implicitly assume in (4) that $\pi_{t}^{w}$ has no immediate effect on $\pi_{t}^{*}$. We find this assumption to be reasonable because our measure of trend inflation captures inflation expectations at an infinite horizon.

${ }^{23}$ We have also experimented with the UC-SV model of Stock and Watson (2007), both with constant and stochastic volatility processes for the shocks in the law of motion of trend inflation. The problem is that the UC-SV model assumes the inflation gap series to be independently distributed error terms (with stochastic variance). This implies a highly volatile inflation trend and causes past inflation and trend inflation to be highly collinear.
} 
We estimate the model using Bayesian MCMC methods, as detailed in Chan et al. (2013), and we drew 55,000 samples and discarded the first 5,000 as burn-in. The results are available upon request. For each country, we keep the median draws from the distribution of trend inflation in order to detrend wage and price inflation, as given in (4).

Table 7 shows the results from table 1 in the first two columns, and columns 3 and 4 show the results for the constant indexation model with time-varying trend inflation. We find that wage indexation to past inflation remains statistically significant in the extended model with trend inflation, although the FE indexation parameter declines in magnitude. The results for the interaction model with time-varying trend inflation (not shown) indicate that our finding of lower and statistically insignificant wage indexation under inflation targeting remains robust. ${ }^{24}$

Table 6: Uniform prior settings for the trend-inflation bounds

\begin{tabular}{lcccc|lcccc}
\hline \hline \multicolumn{1}{c}{ Country } & $\underline{a}$ & $\bar{a}$ & $\underline{b}$ & $\bar{b}$ & \multicolumn{1}{c}{ Country } & $\underline{a}$ & $\bar{a}$ & $\underline{b}$ & $\bar{b}$ \\
\hline Australia & 0 & 1 & 1 & 4 & Italy & 0 & 1 & 1 & 5 \\
Austria & 0 & 1 & 1 & 2.5 & South Korea & 0 & 1 & 1 & 6 \\
Belgium & 0 & 1 & 1 & 2.5 & Netherlands & 0 & 0.5 & 0.5 & 2.5 \\
Canada & 0 & 1 & 1 & 3 & New Zealand & 0 & 0.5 & 0.5 & 3.5 \\
Czech Republic & 0 & 1 & 1 & 4 & Norway & 0 & 0.5 & 0.5 & 3 \\
Denmark & 0 & 1 & 1 & 3.5 & Poland & 0 & 1 & 1 & 15 \\
Estonia & 0 & 1 & 1 & 3 & Portugal & 0 & 1 & 1 & 6 \\
Finland & 0 & 1 & 1 & 3.5 & Slovak Republic & 0 & 1 & 1 & 3 \\
France & 0 & 1 & 1 & 3 & Spain & 0 & 1 & 1 & 5 \\
Germany & 0 & 0.5 & 0.5 & 1.75 & Sweden & 0 & 1 & 1 & 3.5 \\
Hungary & 0 & 1 & 1 & 7 & United Kingdom & 0 & 1 & 1 & 4 \\
Ireland & 0 & 1 & 1 & 5 & United States & 0 & 0.5 & 0.5 & 3 \\
\hline
\end{tabular}

\footnotetext{
${ }^{24}$ We apply robust standard errors which are consistent in the presence of unknown forms of autocorrelation and heteroskedasticity. Note however that we treat trend inflation as a known variable such that the potential generated regressor bias of the standard errors (Pagan 1984) is not taken into account.
} 
Table 7: Results benchmark model and extended model with trend inflation

\begin{tabular}{|c|c|c|c|c|}
\hline \multirow[t]{3}{*}{ Regressand: } & \multicolumn{2}{|c|}{ wage inflation $\left(\pi_{i, t}^{w}\right)$} & \multicolumn{2}{|c|}{ wage gap $\left(\tilde{\pi}_{i, t}^{w}\right)$} \\
\hline & $(1)$ & $(2)$ & $(3)$ & $(4)$ \\
\hline & $\mathrm{FE}$ & CCEP & FE & CCEP \\
\hline Unemployment rate $\left(u_{t}\right)$ & $\begin{array}{l}-0.374^{* * *} \\
(0.089)\end{array}$ & $\begin{array}{l}-0.195^{*} \\
(0.103)\end{array}$ & $\begin{array}{l}-0.381^{* * *} \\
(0.097)\end{array}$ & $\begin{array}{l}-0.168^{* *} \\
(0.082)\end{array}$ \\
\hline Lagged unemployment $\left(u_{t-1}\right)$ & $\begin{array}{l}0.269^{* * *} \\
(0.090)\end{array}$ & $\begin{array}{l}0.108 \\
(0.119)\end{array}$ & $\begin{array}{l}0.277^{* *} \\
(0.109)\end{array}$ & $\begin{array}{l}0.125 \\
(0.085)\end{array}$ \\
\hline Lagged price inflation $\left(\pi_{i, t-1}^{p}\right)$ & $\begin{array}{l}0.806^{* * *} \\
(0.043)\end{array}$ & $\begin{array}{l}0.408^{* * *} \\
(0.091)\end{array}$ & - & - \\
\hline Lagged price gap $\left(\tilde{\pi}_{i, t-1}^{p}\right)$ & - & - & $\begin{array}{l}0.285^{* * *} \\
(0.090)\end{array}$ & $\begin{array}{l}0.456^{* * *} \\
(0.060)\end{array}$ \\
\hline CD test (average correlation) & 0.090 & -0.035 & 0.053 & -0.042 \\
\hline CD test (statistic and p-value) & $\begin{array}{l}15.95 \\
0.000\end{array}$ & $\begin{array}{r}-5.73 \\
0.000 \\
\end{array}$ & $\begin{array}{l}9.77 \\
0.000\end{array}$ & $\begin{array}{r}-6.88 \\
0.000 \\
\end{array}$ \\
\hline $\begin{array}{l}\text { Note: }{ }^{*},{ }^{* *},{ }^{* *} \text { denote significan } \\
\text { Robust standard errors are in b } \\
\text { Sample: } \bar{T}=141, \max T=207, \mathrm{r}\end{array}$ & $\begin{array}{l}\text { at } 10,5 \text {, a } \\
\text { ackets }\end{array}$ & d $1 \%$ leve & respective & \\
\hline
\end{tabular}




\section{References}

Alesina, Alberto, and Lawrence H. Summers. (1993). "Central Bank Independence and Macroeconomic Performance: Some Comparative Evidence." Journal of Money, Credit and Banking 25, 151-62.

Alogoskoufis, George S., and Ron Smith. (1991). "The Phillips Curve, the Persistence of Inflation, and the Lucas Critique: Evidence from Exchange-Rate Regimes." American Economic Review 81, 1254-75.

Benati, Luca. (2008). "Investigating Inflation Persistence Across Monetary Regimes." The Quarterly Journal of Economics 123, 1005-1060.

Borio, Claudio E.V., and William R. White. (2003). "Whither monetary and financial stability: the implications of evolving policy regimes." Proceedings - Economic Policy Symposium - Jackson Hole, Federal Reserve Bank of Kansas City, 131-211.

Brambor, Thomas, William Roberts Clark, and Matt Golder. (2006). "Understanding interaction models: Improving empirical analyses." Political analysis 14, 63-82.

Calmfors, Lars, and John Driffill. (1988). "Bargaining structure, corporatism and macroeconomic performance." Economic policy 3(6), 13-61.

Carrillo, Julio A., Gert Peersman, and Joris Wauters. (2014). "Endogenous Wage Indexation and Aggregate Shocks." CESifo Working Paper Series 4816, CESifo Group Munich.

Cecchetti, Stephen G. (1987). "Indexation and Incomes Policy: A Study of Wage Adjustment in Unionized Manufacturing." Journal of Labor Economics 5, 391-412.

Chan, Joshua C. C., Gary Koop and Simon M. Potter. (2013). "A New Model of Trend Inflation." Journal of Business \& Economic Statistics 31, 94-106.

Christiano, Lawrence J., Martin Eichenbaum and Charles L. Evans. (2005). "Nominal Rigidities and the Dynamic Effects of a Shock to Monetary Policy." Journal of Political Economy 113, 1-45.

Cogley, Tim, and Argia M. Sbordone. (2008). "Trend Inflation, Indexation, and Inflation Persistence in the New Keynesian Phillips Curve." American Economic Review 98, 210126.

Dincer, N. Nergiz, and Barry Eichengreen. (2014). "Central Bank Transparency and Independence: Updates and New Measures." International Journal of Central Banking 10, 189-259.

Eberhardt, Markus. (2012). "Estimating panel time-series models with heterogeneous slopes." Stata Journal 12, 61-71. 
Ehrenberg, Ronald G., Leif Danziger and Gee San. (1983). "Cost-of-Living Adjustment Clauses in Union Contracts: A Summary of Results." Journal of Labor Economics 1, $215-45$.

Eijffinger, Sylvester C.W., and Petra Maria Geraats. (2006). "How transparent are central banks?" European Journal of Political Economy 22, 1-21.

Erceg, Christopher J., Dale W. Henderson and Andrew T. Levin. (2000). "Optimal monetary policy with staggered wage and price contracts." Journal of monetary Economics 46, 281-313.

Fatás, Antonio, Ilian Mihov and Andrew K. Rose. (2007). "Quantitative Goals for Monetary Policy." Journal of Money, Credit and Banking 39, 1163-1176.

Galí, Jordi. (2011). "The Return Of The Wage Phillips Curve." Journal of the European Economic Association 9, 436-461.

Ghosh, Atish R., Anne-Marie Gulde, Jonathan D. Ostry and Holger C. Wolf. (1997). "Does the nominal exchange rate regime matter?" Working Paper 5874, National Bureau of Economic Research.

Gnocchi, Stefano, and Evi Pappa. (2013). "Do labor market institutions matter for business cycles?" Tech. rep., European University Institute.

Gray, Jo Anna. (1978). "On Indexation and Contract Length.” Journal of Political Economy $86,1-18$.

Gürkaynak, Refet S., Andrew T. Levin, Andrew N. Marder and Eric T. Swanson. (2007). "Inflation targeting and the anchoring of inflation expectations in the western hemisphere." Economic Review, 25-47.

Gürkaynak, Refet S., Andrew T. Levin and Eric T. Swanson. (2010). "Does Inflation Targeting Anchor Long-Run Inflation Expectations? Evidence from the US, UK, and Sweden." Journal of the European Economic Association 8, 1208-1242.

Hofmann, Boris, Gert Peersman and Roland Straub. (2012). "Time Variation in U.S. Wage Dynamics." Journal of Monetary Economics 59, 769-783.

Holland, A. Steven. (1986). "Wage indexation and the effect of inflation uncertainty on employment: an empirical analysis." The American Economic Review 76, 235-243.

Houben, Aerdt. C.F.J. (2000). The Evolution of Monetary Policy Strategies in Europe. Boston (Mass.) : Kluwer academic.

Issing, Otmar. (1996). "Is Monetary Targeting in Germany Still Adequate?" In Monetary Policy in an Integrated World Economy: Symposium 1995, edited by Horst Siebert, pp. 117-130. Tübingen. 
Levin, Andrew T., Fabio M. Natalucci and Jeremy M. Piger. (2004). "The macroeconomic effects of inflation targeting." Federal Reserve Bank of St. Louis Review 86, 51-80.

Levy-Yeyati, Eduardo Levy, and Federico Sturzenegger. (2001). "Exchange Rate Regimes and Economic Performance." IMF Staff Papers 47, National Bureau of Economic Research, Inc.

Lucas, Robert E. Jr. (1976). "Econometric policy evaluation: A critique." CarnegieRochester Conference Series on Public Policy 1, 19-46.

Messina, Julián, and Anna Sanz-de-Galdeano. (2014). "Wage Rigidity and Disinflation in Emerging Countries." American Economic Journal: Macroeconomics 6(1), 102-133.

Mishkin, Frederic S. (1999). "International experiences with different monetary policy regimes." Journal of Monetary Economics 43, 579-605.

Mishkin, Frederic S. (2007). "Will Monetary Policy Become More of a Science?" NBER Working Papers 13566, National Bureau of Economic Research, Inc.

Mishkin, Frederic S., and Klaus Schmidt-Hebbel. (2007). "Does Inflation Targeting Make a Difference?" NBER Working Papers 12876, National Bureau of Economic Research, Inc.

Muto, Ichiro, and Kohei Shintani. (2014). "An Empirical Study on the New Keynesian Wage Phillips Curve: Japan and the US." MPRA Paper 53934, University Library of Munich, Germany.

Pagan, Adrian. (1984). "Econometric Issues in the Analysis of Regressions with Generated Regressors." International Economic Review 25, 221-47.

Pesaran, M. Hashem. (2004). "General Diagnostic Tests for Cross Section Dependence in Panels." Cambridge Working Papers in Economics 0435, Faculty of Economics, University of Cambridge.

Pesaran, M. Hashem. (2006). "Estimation and Inference in Large Heterogeneous Panels with a Multifactor Error Structure." Econometrica 74, 967-1012.

Pesaran, M. Hashem, and Ron Smith. (1995). "Estimating long-run relationships from dynamic heterogeneous panels." Journal of Econometrics 68, 79-113.

Ragan, James F., and Bernt Bratsberg. (2000). "Un-COLA: Why Have Cost-of-Living Clauses Disappeared from Union Contracts and Will They Return?" Southern Economic Journal 67, 304-324.

Rose, Andrew K. (2007). "A stable international monetary system emerges: Inflation targeting is Bretton Woods, reversed." Journal of International Money and Finance 26, 663-681.

Smets, Frank, and Rafael Wouters. (2007). "Shocks and Frictions in US Business Cycles: A Bayesian DSGE Approach." American Economic Review 97, 586-606. 
Sterne, Georgios, David Stasavage, and Gabriel Chortareas. (2002). "Does it pay to be transparent? International evidence from central bank forecasts." Federal Reserve Bank of St. Louis Review 84.

Stock, James. H., and Mark W. Watson. (2007). "Why Has U.S. Inflation Become Harder to Forecast?" Journal of Money, Credit and banking 39, 3-33.

Svensson, Lars E. O. (1999). "Inflation targeting as a monetary policy rule." Journal of Monetary Economics 43, 607-654.

Visser, Jelle. (2013). "ICTWSS database on institutional characteristics of trade unions, wage setting, state intervention and social pacts in 34 countries between 1960 and 2007." Amsterdam Institute for Advanced Labour Studies, University of Amsterdam, Amsterdam, version 4.0.

Walsh, Carl E. (2009). "Inflation Targeting: What Have We Learned?" International Finance 12, 195-233.

Wieland, Volker. (2009). "Learning, Endogenous Indexation, and Disinflation in the NewKeynesian Model." in Monetary Policy under Uncertainty and Learning, edited by Klaus Schmidt-Hebbel, Carl. E. Walsh, and Norman Loayza, pp 413-450. Central Bank of Chile. 